\title{
Rhizometer: An Apparatus to Observe and Measure Root Growth and Its Effect on Container Substrate Physical Properties Over Time
}

\author{
Lesley A. Judd ${ }^{1,4}$, Brian E. Jackson ${ }^{2}$, and William C. Fonteno ${ }^{3}$ \\ North Carolina State University, Department of Horticultural Science, 227 \\ Kilgore Hall, Campus Box 7609, Raleigh, NC 27695
}

Additional index words. air space, container capacity, rhizosphere

\begin{abstract}
Container production of plants use substrates that are formulated to have adequate physical properties to sustain optimal plant growth; however, these properties can change over time as a result of substrate settling and root growth of the growing plant in the container. An apparatus (rhizometer) was developed that measures the changes caused by plant roots on physical properties of substrates during crop production in containers. The design of the rhizometer included a clear core, which allowed for observing and measuring a range of root system characteristics in situ, including total root length visible along the rhizometer. Physical properties of planted and fallow rhizometers were measured, and the effect of four species on substrate physical properties was determined. There was a general decrease in substrate total porosity and air space (AS) over time with both fallow and planted rhizometers as a result of both settling of the substrate and root growth into the substrate. Container capacity did not change over time with or without roots. Plants with large root systems such as Begonia $\times$ hybrida acut. decreased AS over time, whereas plants of Rudbeckia hirta L. with a smaller root system did not have the same effect. Measured total root length was highly correlated to the total dry root mass of Tagetes erecta L. and Zinnia marylandica D.M. Spooner, Stimart \& T. Boyle plants. This may allow tracing and measuring root lengths to be another (alternative) method to measure root systems. Planted rhizometers also allowed easy access for viewing the root system non-destructively, providing the ability to observe and measure root growth.
\end{abstract}

Approximately $90 \%$ of the $\$ 16$ billion greenhouse, nursery, and floriculture industries are generated from plants produced in containers, excluding food crops grown under cover (U.S. Department of Agriculture, 2009). This industry includes bedding plants, foliage plants, potted flowering plants, potted nursery stock, and other floriculture/nursery crops, all grown in a wide variety of container types and sizes as well as different substrates. Plants grown in containers are generally limited by the volume of substrate in which water, gas, and solute availability can fluctuate over a short period of time (Polak and Wallach, 2001). Physical properties of substrates known to affect roots include AS, container capacity (CC), total porosity (TP), percentage of fine particles, and bulk density (BD; Baligar and Nash, 1978; Mathers et al., 2007). These physical properties are not only

Received for publication 28 Oct. 2014. Accepted for publication 9 Dec. 2014.

This paper is a portion of a thesis submitted by Lesley A. Judd as required to fulfill degree requirements.

${ }^{1}$ Graduate Research Assistant.

${ }^{2}$ Assistant Professor.

${ }^{3}$ Professor

${ }^{4}$ To whom reprint requests should be addressed; e-mail lajudd@ncsu.edu. important to root growth, but also to cultural practices like decisions on container type/ size and irrigation strategy. According to Cannavo et al. (2011), AS, CC, and water availability have a considerable impact on plant growth. The pores of a substrate allow for drainage and pores devoid of water allow for gas exchange between the root environment and the outside atmosphere (Bunt, 1988).

For container-grown plants, the stability of the substrate's physical properties is of primary concern because changes in these properties may adversely affect plant growth (Allaire-Leung et al., 1999). The influence of root growth on the physical properties of substrates is poorly documented with unconvincing and contradictory results (Cannavo et al., 2011). As plant roots grow into the container substrate, there can be modification of TP, pore size distribution, and pore connectivity (Cannavo et al., 2011). According to Allaire-Leung et al. (1999), root growth leads to a decrease in porosity as the roots grow in the gaseous phase of the porosity, i.e., the macroporosity. The diameter of roots also seems to be a good predictor of the effect of mechanical impedance and substrate pore size, because data obtained by Baligar and Nash (1978) and Wiersum (1957) demonstrate that a root is only able to penetrate a pore that has a diameter exceeding that of a young root. Goss (1977) reported that mechanical impedance caused plants to grow superficial and densely branched root systems where the roots did not grow past $8 \mathrm{~cm}$ of depth. Other factors may include the size of the container and temperature of the substrate while the roots are growing in it. The AS and CC of a substrate are dependent on the container depth and width as well as the type of substrate (Bilderback and Fonteno, 1987).

There are several ways to measure physical properties of substrates mentioned in scientific literature. One common procedure is measuring TP, CC, and AS with the North Carolina State University (NCSU) porometer method (Fonteno, 1996; Fonteno et al., 1995). The NCSU porometer method uses aluminum $7.6-\mathrm{cm}$ tall cylinders (cores) to measure substrate physical properties. The porometer can measure physical properties of a substrate-packed core; however, there is little documentation of the effects of substrate organic component decomposition resulting from the difficulty of measuring physical property changes over time (Bilderback et al., 2005). Analyses of initial substrate physical properties at potting can be compared with the end of the production cycle; Owen et al. (2008) and Warren and Bilderback (1992) buried cores in fallow containers at potting and then extracted the cores (naturally compacted/settled) at the end of production to measure final physical properties. The procedure of burying cores in fallow containers can be difficult because the researcher is required to have the equipment for physical property analysis and laboratory cores are tied up for long periods of time (Bilderback et al., 2005). Jackson et al. (2008) packed cores using substrate from fallow containers after simulated plant production experiment to determine final physical properties and how they changed over time since potting. Their data were used to assess substrate particle decomposition over time in a production situation and how the decomposition changes physical properties. They did not and could not assess the actual physical properties in the container at the end of their experiment because the substrate was not measured in situ. Bilderback et al. (2005) reported that changes in substrate over time such as BD are difficult to reproduce when packing cores for laboratory analysis.

These procedures for measuring changes in substrate physical properties over time did not include the effects of plant roots growing in the substrates. To investigate this, Nelson et al. (2004) described using planted greenhouse containers, plugging the holes in the bottom of the container, and saturating the substrate to measure AS and CC. Results from their study showed AS decreasing and $\mathrm{CC}$ increasing during crop production and no consistent change in BD. Altland et al. (2011) used $15.2-\mathrm{cm}$ tall aluminum cores to grow nursery crops in pumice and measured the changes in AS and TP using the porometer method. Observed overall treatments was 
a decrease in AS with an increase in $\mathrm{CC}$ and $\mathrm{TP}$, whereas $\mathrm{BD}$ remained constant over time. It was also noted that the presence of the plant in the core tended to exacerbate the decrease in AS and the increase in $\mathrm{CC}$, and shrinkage was decreased minimally by the presence of a plant (Altland et al., 2011).

Root growth of a plant itself can be an important measurement for understanding the substrate environment and its influence on root growth and vice versa. However, root growth measurements are frequently excluded in horticultural research (Wright and Wright, 2004) and the study of natural root development is a challenge as a result of the difficulty of observing and measuring roots in containers during crop production (Silva and Beeson, 2011). One of the most common ways to evaluate root systems is to destructively extract a root system from its growing substrate by washing and then drying the roots for a measureable weight. However, it is possible with washing and even storing root samples to have losses of $\approx 20 \%$ to $40 \%$ dry weight (Oliveira et al., 2000; van Noordwijk and Floris, 1979).

A transparent device/container could aid in observing root growth and the use of digital imaging could potentially be used to quantify root systems. Digital imaging includes photographs or videos, scanned images of exposed roots, or scanned root tracings. These images can be used by computer programs to evaluate root systems. There are numerous computer programs, both commercially and freely available, that can be used, and there are 19 commonly used and known computer programs (Lobet et al., 2013). Some of these programs include RootLM, RootReader 2D, EZ-Rhizo, WinRHIZO and WinRHIZO Tron. RootReader 2D was developed at Cornell University, and images of intact root systems can be uploaded into the program and root growth responses quantified from whole root systems or specific roots of interest (Clark et al., 2013).

Based on the work of Altland et al. (2011) and Fonteno (1996), an apparatus was designed (rhizometer) as a new root and substrate measurement technique. The name rhizometer stems from rhizo, meaning rhizosphere, and -ometer or -meter, from the term porometer and an instrument used in scientific measuring. The rationale of this apparatus was to measure both the physical properties of substrates during plant production and the effects of growing roots on substrates while also having the ability to observe and measure roots in situ. The objectives of these studies were 1) to compare the effects of different plant root types on substrate physical properties over time; and 2) test the ability and potential of measuring roots systems with digital analysis through rhizometers.

\section{Materials and Methods}

Construction of a rhizometer. Clear cylindrical Plexiglas ${ }^{\circledR}$ tubes $(7.6 \mathrm{~cm}$ i.d. $\times 1.8 \mathrm{~m}$;
Arkema, Inc., Chatham, VA) were cut into 7.6- $\mathrm{cm}$ tall sections to make a core cylinder of the same dimensions as the aluminum NCSU porometer cores. This facilitated the rhizometer cores fitting into the base plates and funnel used in the NCSU porometer method (Fig. 1). The porometer procedure requires a level core; however, watering over time would cause the substrate to settle and/or shrink. Another consideration of the design process included the impact of a plug or seed planted in the rhizometer; to not affect the substrate physical properties with placing a seed/plug in the substrate or having the plug itself in the part of the rhizometer used in the porometer method, the rhizometer needed to be taller for extra substrate space. The solution to these issues was to include an attachment (collar), which would be affixed on top of the main core (Fig. 2). The collars were removable, and to prepare the rhizometers for the porometer method, the collars were removed and the excess substrate removed (including any remaining plug/seed part) and leveled to the top of the 7.6- $\mathrm{cm}$ core. These collars were also cut from the Plexiglas ${ }^{\circledR}$ tube, $3.8 \mathrm{~cm}$ tall $\times 7.6$ i.d., and attached to the top of the core with parafilm $\mathrm{M}^{\circledR}$ (American Can Company, Greenwich, CT) when the rhizometers were assembled Mesh screen $(18 \times 16$-square mesh, Model 13507; New York Wire, York, PA) was cut in $11.5 \mathrm{~cm} \times 11.5-\mathrm{cm}$ squares to fit the bottom of the core and held in place with an adjustable metal hose clamp (MintCraft ${ }^{\mathrm{TM}}$

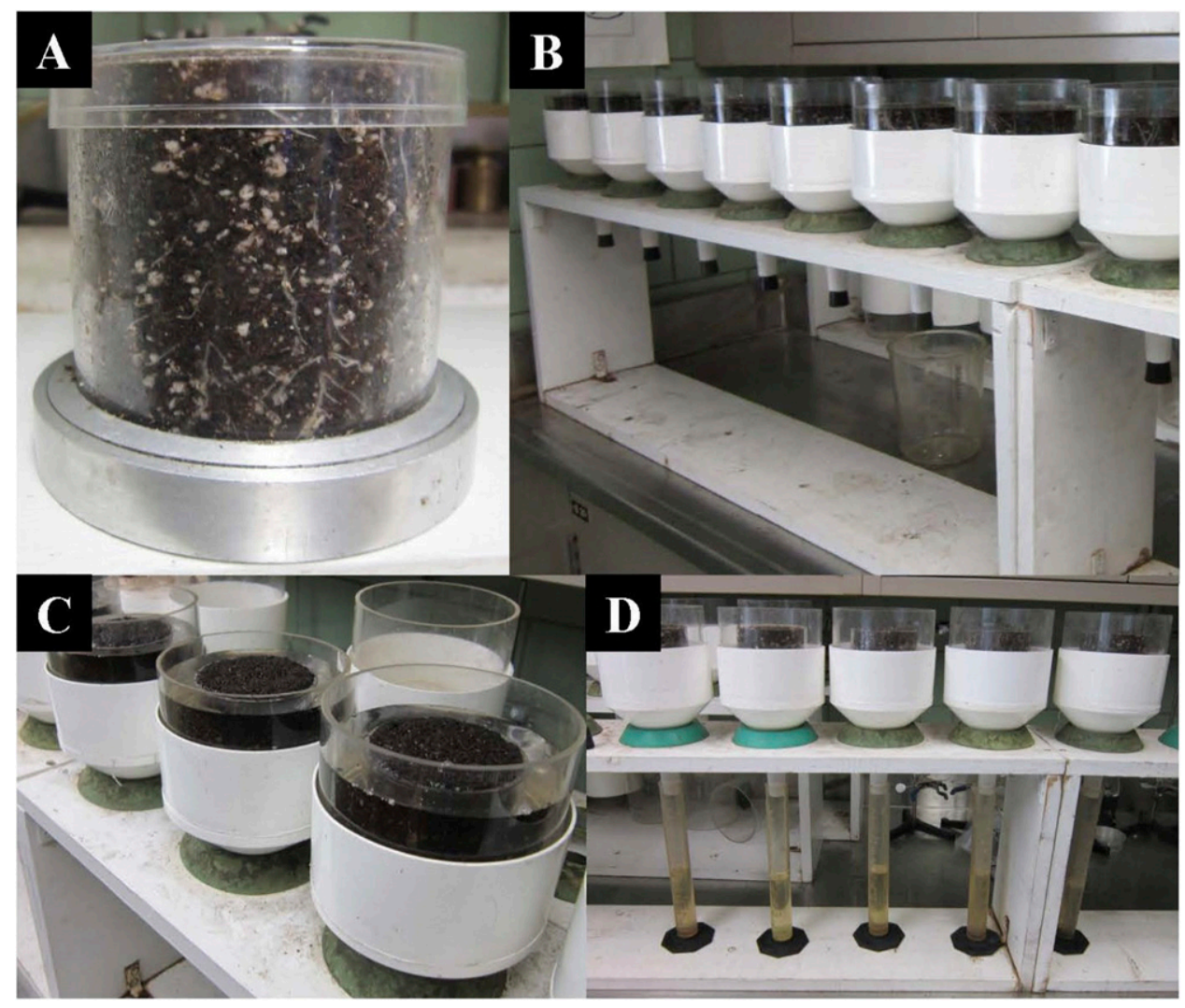

Fig. 1. (A) Rhizometer readied and situated into the NCSU porometer base plate and then (B) placed in the funnels of the porometer method and substrate was saturated with water. (C) View of the water level with the top of the rhizometer to allow for complete substrate saturation. (D) Water inside the rhizometers is allowed to drain and captured to measure air space. 


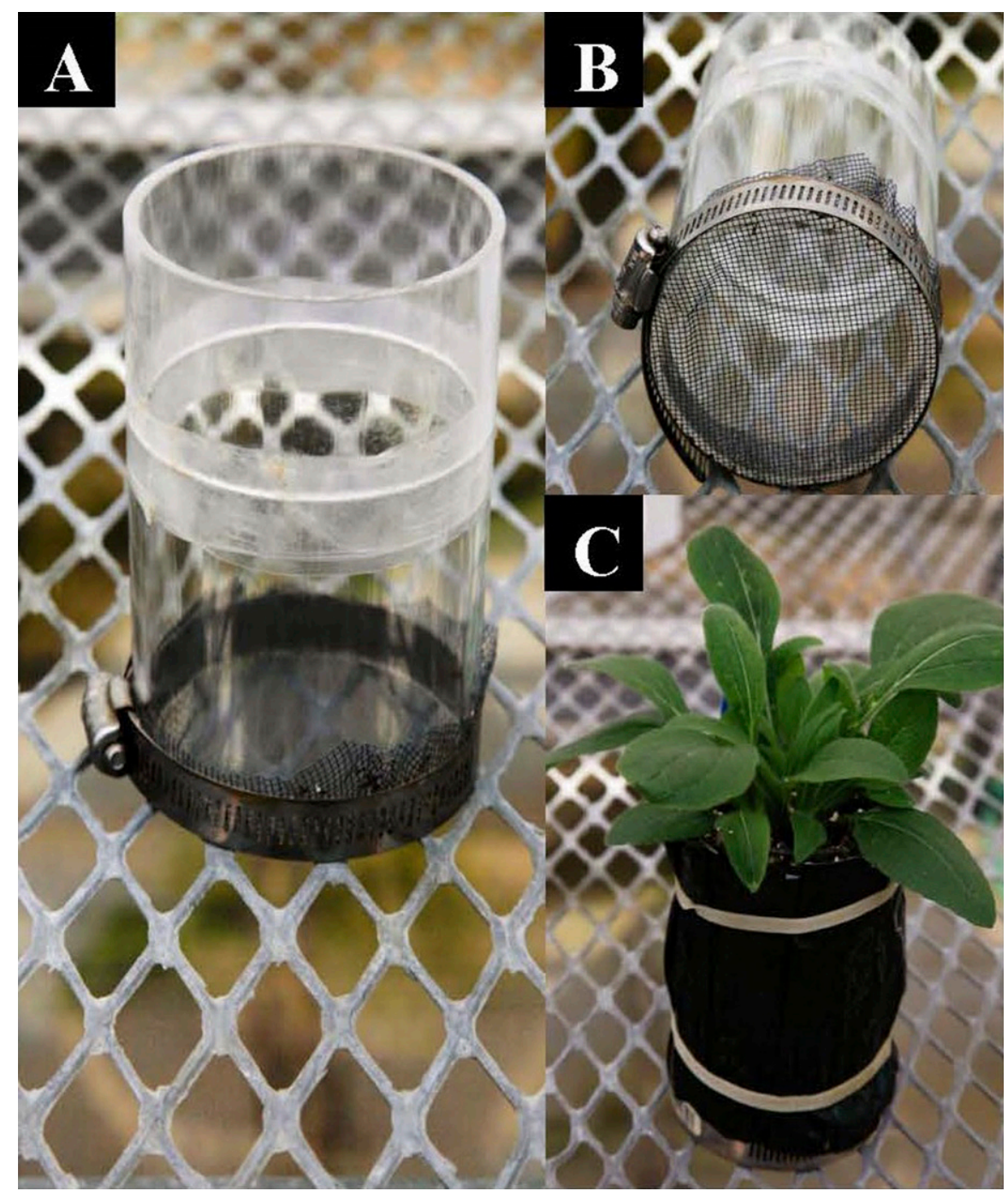

Fig. 2. (A) Design of rhizometer illustrating the clear-sided Plexiglas ${ }^{\circledR}$ allowing for root observations and measurements and the attached collar, (B) the screened bottom, and $(\mathbf{C})$ a complete planted rhizometer with foil attached for light exclusion.

\#56, 78 to $101 \mathrm{~mm}$ with $1.3-\mathrm{cm}$ band; Burke Brothers Hardware, Raleigh, NC; Fig. 2). The screen on the bottom of the rhizometers allowed for irrigation drainage, held the substrate in the rhizometers, and aided in air pruning of plant roots. The screen was held in place with a detachable metal clamp so it could be replaced with the NCSU porometer base plate to measure the physical properties. Dark-colored pot sleeves (foil) were placed over the rhizometers and held in place with rubber bands to restrict light from the root system.

Root effects on physical properties. On 14 Mar. 2012, marigold (Tagetes erecta 'Inca Orange') seeds (Wyatt-Quarles Seed Co., Garner, NC) were sown into 288-plug trays [1.5 long $\times 1.5$ wide $\times 3.5$ high $(\mathrm{cm})]$ containing Fafard Germination mix (Fafard, Anderson, SC) in a greenhouse in Raleigh, NC. On 18 May 2012, 60 rhizometers were filled with a moistened 3 peat: 1 perlite: 1 vermiculite (by volume) substrate, which had an initial pH of 5.8. The weight of each rhizometer was recorded and $105 \mathrm{~g}$ of substrate was added to each rhizometer. At time of planting, the substrate had a mass wetness of $1.5\left(\mathrm{~g} \cdot \mathrm{g}^{-1}\right)$, which assured similar packing and substrate volume in the rhizometers and prevented potential hydrophobicity or swelling when watered. Each rhizometer was tapped five times by dropping the filled rhizometers from a height of $10 \mathrm{~cm}$ on a flat surface to achieve similar BD in every core, mimicking the porometer packing process. On 18 May 2012, marigold plugs were planted into packed rhizometers by creating a 2-cm hole in the center of the collar of 40 rhizometers and placing the marigold plug into the hole, thereby minimally disturbing the packed nature of the rhizometer core. Twenty rhizometers were not planted (fallow) to allow for measurements of undisturbed (i.e., no root growth) physical properties. Rhizometers were completely randomized on a greenhouse bench in Raleigh, NC. All rhizometers were overhead-watered by hand using a greenhouse hose with a water breaker as needed depending on weather conditions $(\approx 200 \mathrm{~mL}$ each time) and never showed symptoms of water stress. The fallow rhizometers were watered as well so the effects of irrigation and resultant substrate settling would be similar in fallow and planted rhizometers. Rhizometers (fallow and planted) were fertilized at each watering with $200 \mathrm{mg} \cdot \mathrm{L}^{-1}$ nitrogen derived from 20N-4.4P-16.6K (Peatlite Special, Peters Professional; The Scotts Co., Marysville, $\mathrm{OH}$ ) and injected at $1: 100$ ratio by a Dosatron injector [(D14MZ2); Dosatron International, Inc., Clearwater, FL].

For 4 consecutive weeks after planting, 15 rhizometers were chosen randomly and removed from the greenhouse. Of the 15 rhizometers, five planted and five fallow were prepared for testing in the NCSU porometer method, as described by Fonteno (1996). For the remaining five planted rhizometers, the marigolds were harvested at the base of the substrate and all substrate was carefully washed from the root systems, and roots were dried to determine root biomass. This was conducted so that data of root growth mass over time were known and could be correlated with the changes in substrate physical properties. To prepare the rhizometer for the porometer method, shoots were severed at the base of the substrate and the collar extension was removed, revealing 1 to $2 \mathrm{~cm}$ of substrate above the $7.6-\mathrm{cm}$ core. This substrate and any roots above the main core were carefully removed such that the substrate within the core was level with the top of the core. The screen covering the bottom of each rhizometer was removed so that the apparatus could be inserted into the base plate used in the porometer method (Fig. 1). The rhizometer was then processed through the NCSU porometer procedure to determine physical properties, including TP, AS, and CC. Means separation using least significant difference (LSD; $P \leq 0.05$ ) was used to compare means of fallow vs. planted physical properties and root dry mass (Version 9.2; SAS Institute, Cary NC).

Comparison of root types. Except where indicated, procedures for Expt. 2 were as described for Expt. 1. On 19 July 2012, 100 rhizometers were filled with a 3 peat: 1 perlite: 1 vermiculite (by volume) substrate, which had an initial $\mathrm{pH}$ value of 5.8. For this study, two plant species with different root types were used to examine the change of substrate physical properties during production. For small roots, rudbeckia (Rudbeckia hirta 'Becky Yellow'; 288-tray; C. Raker \& Sons, Inc., Litchfield, MI) plugs were planted in 40 rhizometers. For larger roots, begonia (Begonia ×hybrida 'Dragon Wing Red'; 128-tray; C. Raker \& Sons, Inc.) plugs were planted in 40 rhizometers. The remaining 20 rhizometers were fallow and used in the same manner as Expt. 1. Rhizometers were randomly arranged by species with 10 fallow rhizometer randomly interspersed among the two species on a greenhouse bench in Raleigh, NC, and watered as described in Expt. 1. Physical properties and root mass data were analyzed as described in Expt. 1.

Measuring roots in the rhizometer. Except where indicated, procedures for Expt. 3 
were as described for Expt. 1. On 25 June 2014, 60 rhizometers were filled with a 3 peat: 1 perlite: 1 vermiculite (by volume) substrate, which had an initial pH value of 5.8. Zinnia (Zinnia marylandica 'Zahara Cherry'; 288-tray; C. Raker \& Sons, Inc.) plugs were planted in 40 rhizometers. The remaining 20 rhizometers were fallow, to be used in the same manner as Expt. 1. All rhizometers were randomly arranged on a greenhouse bench in Raleigh, NC, and watered as described in Expt. 1. On the planted rhizometers pulled each week to be harvested, roots that could be seen through the Plexiglas ${ }^{\circledR}$ rhizometer walls were traced. Root tracing was accomplished using a transparency sheet $(27.9 \mathrm{~cm} \times 7.6-\mathrm{cm}$ transparency film; $3 \mathrm{M}$ Visual Systems Division, Austin, TX) cut to the dimensions of the rhizometer and wrapped around the core and held in place with a rubber band. Cumulative root length could then be measured on every rhizometer by tracing the roots on the transparency sheet with a thin-tipped, wet-erase transparency marker, taking a digital photograph of the traced roots, and uploading the image to root reading software (RootReader 2D Version 4.3.1; Cornell University, USDA-ARS, Ithaca, NY). The RootReader 2D software selected the traced roots and measured total root length of the entire picture. The tracing on the transparency sheet was then erased to remove the ink and the sheet was used for the next tracing. Means separation using LSD $(P \leq 0.05)$ was used to compare means of total root length for each harvest date, and PROC CORR was used to analyze possible correlation between total root length and dry root mass for each plant replication at each measurement date (Version 9.4; SAS Institute). Physical properties and root mass data were analyzed as described in Expt. 1.

The study was repeated with a different plant species on 30 July 2014. Sixty rhizometers were filled with a 3 peat: 1 perlite: 1 vermiculite (by volume) substrate, which had an initial $\mathrm{pH}$ value of 5.8. Marigold (Tagetes erecta 'Inca Orange'; 288-tray; C. Raker \& Sons, Inc.) plugs were planted in 40 rhizometers. The remaining 20 rhizometers were fallow, to be used in the same manner as Expt. 1. All rhizometers were randomly arranged on a greenhouse bench in Raleigh, $\mathrm{NC}$, and watered as described in Expt. 1. Root tracing was performed on planted rhizometers harvested weekly. Physical properties, root total length, and root mass data were analyzed as previously described.

\section{Results and Discussion}

Root effects on physical properties. For the 2012 experiment comparing the physical properties between planted and fallow rhizometers, CC was not different over time (Table 1). A linear decrease was observed with AS over time in both the fallow and marigold-planted rhizometers (Table 1). At $7 \mathrm{~d}$ after planting (DAP), planted rhizometers had a lower AS than the fallow rhizometers ( $16.6 \%$ vs. $20.0 \%$ volume, respectively), and

Table 1. Physical properties of 3 peat: 1 perlite: 1 vermiculite (by volume) substrate with or without the presence of 'Inca Orange' marigold (Tagetes erecta) plants growing in the rhizometer and root dry weight data for marigold plants grown over 4 weeks in 2012 and 2014.

\begin{tabular}{|c|c|c|c|c|c|}
\hline \multirow[b]{4}{*}{ Rhizometer } & \multirow[b]{4}{*}{$\mathrm{DAP}^{\mathrm{v}}$} & \multicolumn{3}{|c|}{ Expt. 1: 2012} & \multirow{4}{*}{$\begin{array}{l}\text { Root dry } \\
\text { mass }^{\mathrm{u}}(\mathrm{g})\end{array}$} \\
\hline & & \multicolumn{3}{|c|}{ Physical properties ${ }^{z}$} & \\
\hline & & Container capacity & Air space ${ }^{\mathrm{x}}$ & Total porosity $^{\mathrm{w}}$ & \\
\hline & & & $(\% \mathrm{vol})$ & & \\
\hline \multirow[t]{5}{*}{ Planted } & 7 & $74.1 \mathrm{a}^{\mathrm{t}}$ & $16.6 \mathrm{~b}$ & $90.7 \mathrm{~b}$ & $0.10 \mathrm{~b}^{\mathrm{s}}$ \\
\hline & 14 & $77.2 \mathrm{a}$ & $14.6 \mathrm{~b}$ & $91.8 \mathrm{~b}$ & $0.22 \mathrm{~b}$ \\
\hline & 21 & $74.8 \mathrm{a}$ & $15.1 \mathrm{a}$ & $89.9 \mathrm{~b}$ & $0.69 \mathrm{a}$ \\
\hline & 28 & $75.6 \mathrm{a}$ & $13.2 \mathrm{~b}$ & $88.8 \mathrm{~b}$ & $0.95 \mathrm{a}$ \\
\hline & & $\mathrm{NS}^{\mathrm{r}}$ & $\mathrm{L}^{* *}$ & $\mathrm{Q}^{*}$ & $\mathrm{~L}^{* * *}$ \\
\hline \multirow[t]{5}{*}{ Fallow } & 7 & $73.7 \mathrm{a}$ & $20.0 \mathrm{a}$ & $93.7 \mathrm{a}$ & \\
\hline & 14 & $74.6 \mathrm{a}$ & $18.4 \mathrm{a}$ & $93.0 \mathrm{a}$ & \\
\hline & 21 & $75.4 \mathrm{a}$ & $16.6 \mathrm{a}$ & $92.0 \mathrm{a}$ & \\
\hline & 28 & $75.0 \mathrm{a}$ & $16.8 \mathrm{a}$ & $91.8 \mathrm{a}$ & \\
\hline & & NS & $\mathrm{L}^{* *}$ & $\mathrm{~L}^{* *}$ & \\
\hline \multicolumn{6}{|c|}{ Expt. 3: 2014} \\
\hline \multirow[t]{5}{*}{ Planted } & 7 & $76.9 \mathrm{a}$ & $13.5 \mathrm{a}$ & $90.5 \mathrm{a}$ & $0.13 \mathrm{c}$ \\
\hline & 14 & $80.0 \mathrm{a}$ & $9.8 \mathrm{~b}$ & $89.8 \mathrm{a}$ & $0.12 \mathrm{c}$ \\
\hline & 21 & $80.0 \mathrm{a}$ & $9.1 \mathrm{~b}$ & $89.1 \mathrm{~b}$ & $0.24 \mathrm{~b}$ \\
\hline & 28 & $79.6 \mathrm{a}$ & $9.9 \mathrm{~b}$ & $89.8 \mathrm{~b}$ & $0.46 \mathrm{a}$ \\
\hline & & NS & $\mathrm{Q}^{* *}$ & NS & $\mathrm{Q}^{* * *}$ \\
\hline \multirow[t]{5}{*}{ Fallow } & 7 & $77.2 \mathrm{a}$ & $13.5 \mathrm{a}$ & $90.7 \mathrm{a}$ & \\
\hline & 14 & $77.9 \mathrm{a}$ & $13.4 \mathrm{a}$ & $91.3 \mathrm{a}$ & \\
\hline & 21 & $78.3 \mathrm{~b}$ & $11.9 \mathrm{a}$ & $90.2 \mathrm{a}$ & \\
\hline & 28 & $77.8 \mathrm{a}$ & $13.6 \mathrm{a}$ & $91.3 \mathrm{a}$ & \\
\hline & & NS & NS & NS & \\
\hline \multicolumn{6}{|c|}{ Expt. 1: 2012} \\
\hline Plant & & $\mathrm{NS}^{\mathrm{q}}$ & $* * *$ & **** & \\
\hline Root dry mass & & NS & $*$ & ** & \\
\hline Interaction & & NS & $*$ & $* *$ & \\
\hline \multicolumn{6}{|c|}{ Expt. 3: 2014} \\
\hline Plant & & NS & ** & $* *$ & \\
\hline Root dry mass & & NS & NS & NS & \\
\hline Interaction & & NS & NS & NS & \\
\hline
\end{tabular}

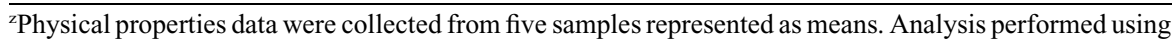
the North Carolina State University porometer method (Fonteno, 1996; Fonteno et al., 1995).

${ }^{y}$ Container capacity is (wet weight - oven dry weight) $\div$ volume of the sample.

${ }^{\mathrm{x}}$ Air space is the volume of water drained from the sample $\div$ volume of the sample.

${ }^{\text {wTotal }}$ porosity $=$ container capacity + air space.

${ }^{\vee} \mathrm{DAP}=$ days after planting.

"Root dry mass from washed root systems and oven-dried.

'Means separated between planted and fallow rhizometers for each DAP of individual physical properties using least significant difference (LSD), $P \leq 0.05$. Means followed by the same letter are not significantly different.

${ }^{s}$ Means separated within column for root dry mass using LSD, $P \leq 0.05$. Means followed by the same letter are not significantly different.

${ }^{\mathrm{r}} \mathrm{NS}$, L, and Q represent no significant response, linear, and quadratic response, respectively, of individual physical properties over time, ${ }^{*}, * * * * *$ represent significant effects when $P \leq 0.05,0.01$, and 0.001 , respectively.

${ }_{\mathrm{N}}^{\mathrm{NS}, *, * *}, * * *$ represent no significant effect, or significant effects when $P \leq 0.05,0.01$, and 0.001 , respectively.

this trend was observed to the end of the study (13.2\% vs. $16.8 \%$, respectively), except at 21 DAP when AS was not different between planted and fallow rhizometers (Table 1). A linear decrease was also observed in TP for the fallow rhizometers and a quadratic decrease for the planted rhizometers (Table 1). Planted rhizometers had a lower TP $(89 \%$ to $92 \%$ ) compared with the fallow rhizometers ( $92 \%$ to $94 \%$ ) from 7 to 28 DAP, which can be attributed to the decrease in AS.

For the 2014 experiment with marigold plants, similar results were observed. Container capacity changed little over time and mean separation indicated no differences except at 21 DAP when fallow rhizometers had a lower CC compared with marigold-planted rhizometers (Table 1). For the marigold-planted rhizometers, TP differences were found at 21 and 28 DAP with planted rhizometers having a lower TP compared with fallow rhizometers. However, TP for both planted and fallow rhizometers showed little change over time. AS also decreased over time and was significantly lower from 14 to 28 DAP compared with the fallow rhizometers. At 7 DAP, planted rhizometers had the same AS compared with the fallow rhizometers (13.5\%); however, at the end of the study, there was a larger difference 
( $10 \%$ vs. $14 \%$, respectively), and a similar $4 \%$ difference was observed in the 2012 experiment. However, for the 2014 experiment, there was no change in AS over time for the fallow rhizometers, unlike the 2012 study (Table 1).

Nelson et al. (2004) reported a similar pattern in a study with peat and coir substrates where settling caused a decrease in AS and an increase in $\mathrm{CC}$, and this was thought to be the conversion of large pores (i.e., AS) into smaller pores for holding water (i.e., CC). Marigold root growth in the planted rhizometers increased rapidly over time (Table 1); and the change in AS, and therefore TP, may be explained by the presence of the roots in the rhizometers. Other authors have reported decrease in AS over time with peat-based substrates with the presence of a plant (Aendekerk, 1997; Allaire-Leung et al., 1999; Cannavo and Michel, 2013; Nelson et al., 2004). As these authors noted, there is a decrease in AS as a result of settling and slight decomposition of the peat-based substrates (Aendekerk, 1997; Allaire-Leung et al., 1999; Nelson et al., 2004). However, the lower AS observed in this study shows that the presence of roots further decreases AS compared with the decrease in AS of the fallow rhizometers in 2012, similar to results reported by Altland et al. (2011) in nursery substrates amended with pumice. As the roots grew, it is possible that they filled the pore space, therefore causing a decrease in substrate AS. Altland et al. (2011) reasoned that as roots explore the substrate and displace some of the pore spaces, AS is expected to decrease over time. In these experiments, although the physical and root data did not come from the same samples, it seemed that the roots occupied $\approx 4 \%$ volume compared with the fallow samples and that the volumes consumed by the roots came from the larger pores for AS.

Comparison of root types. Container capacity was similar between fallow and planted rhizometers of begonia and rudbeckia at every harvest date except the first (7 DAP), when fallow rhizometers had a lower CC than the begonia rhizometers (Table 2). The begonia rhizometers had decreasing AS and TP over time, similar to marigolds in the previous experiment. The difference in AS at 28 DAP was almost $10 \%$ by volume from plant to fallow samples, which was also the approximate difference in TP. The rudbeckia rhizometers had no change in AS and TP over time and were similar to fallow rhizometers from 7 to 21 DAP. The root dry mass of begonia was also larger at every harvest date compared with the rudbeckia root dry mass (Table 2). From this experiment, the plant species with the larger root system had a greater effect on substrate physical properties. Increasing root growth of begonia led to a decrease in AS, whereas increasing root growth of rudbeckia did not measurably change the physical properties perhaps because the root dry mass of rudbeckia was approximately half that of begonia. Analyzing the correlation between

Table 2. Physical properties of 3 peat:1 perlite: 1 vermiculite (by volume) substrate with or without either 'Dragon Wing Red' begonia (Begonia $\times$ hybrida) or 'Becky Yellow' rudbeckia (Rudbeckia hirta) growing in the rhizometer and root dry weight data over 4 weeks in 2012.

\begin{tabular}{|c|c|c|c|c|c|}
\hline \multirow[b]{3}{*}{ Rhizometer } & \multirow[b]{3}{*}{ DAP $^{v}$} & \multicolumn{3}{|c|}{ Physical properties $^{z}$} & \multirow{3}{*}{$\begin{array}{l}\text { Root dry } \\
\operatorname{mass}^{\mathrm{u}}(\mathrm{g})\end{array}$} \\
\hline & & Container capacity $^{\mathrm{y}}$ & Air space ${ }^{x}$ & Total porosity ${ }^{\mathrm{w}}$ & \\
\hline & & \multicolumn{3}{|c|}{$(\% \mathrm{vol})$} & \\
\hline \multirow[t]{5}{*}{ Planted begonia } & 7 & $82.1 \mathrm{a}^{\mathrm{t}}$ & $8.0 \mathrm{~b}$ & $90.1 \mathrm{a}$ & $0.51 \mathrm{a}^{\mathrm{s}}$ \\
\hline & 14 & $80.0 \mathrm{a}$ & $9.9 \mathrm{a}$ & 89.9 a & $0.49 \mathrm{a}$ \\
\hline & 21 & $78.0 \mathrm{a}$ & $5.4 \mathrm{~b}$ & $83.4 \mathrm{~b}$ & $1.10 \mathrm{a}$ \\
\hline & 28 & $76.9 \mathrm{a}$ & $5.9 \mathrm{~b}$ & $82.8 \mathrm{~b}$ & $1.20 \mathrm{a}$ \\
\hline & & $\mathrm{L} * * * \mathrm{r}$ & $\mathrm{L}^{*}$ & $\mathrm{Q}^{* * *}$ & $\mathrm{~L} * * *$ \\
\hline \multirow[t]{5}{*}{ Planted rudbeckia } & 7 & $79.9 \mathrm{ab}$ & $11.2 \mathrm{ab}$ & $91.1 \mathrm{a}$ & $0.11 \mathrm{~b}$ \\
\hline & 14 & $79.3 \mathrm{a}$ & $12.9 \mathrm{a}$ & $92.2 \mathrm{a}$ & $0.08 \mathrm{~b}$ \\
\hline & 21 & $79.6 \mathrm{a}$ & $8.7 \mathrm{ab}$ & $88.3 \mathrm{ab}$ & $0.39 \mathrm{~b}$ \\
\hline & 28 & $79.2 \mathrm{a}$ & $11.2 \mathrm{a}$ & $90.4 \mathrm{a}$ & $0.58 \mathrm{~b}$ \\
\hline & & NS & NS & NS & $\mathrm{L} * * *$ \\
\hline \multirow[t]{5}{*}{ Fallow } & 7 & $76.6 \mathrm{~b}$ & $14.3 \mathrm{a}$ & $90.9 \mathrm{a}$ & \\
\hline & 14 & $79.0 \mathrm{a}$ & $12.0 \mathrm{a}$ & $91.0 \mathrm{a}$ & \\
\hline & 21 & $79.1 \mathrm{a}$ & $11.0 \mathrm{a}$ & $90.1 \mathrm{a}$ & \\
\hline & 28 & $79.0 \mathrm{a}$ & $15.1 \mathrm{a}$ & $94.1 \mathrm{a}$ & \\
\hline & & $\mathrm{L}^{*}$ & NS & NS & \\
\hline Plant interaction & & $\mathrm{NS}^{\mathrm{q}}$ & $* * *$ & $* * *$ & \\
\hline Root dry mass-Rudbeckia & & NS & NS & $*$ & \\
\hline Root dry mass-Begonia & & $* *,-0.60^{\mathrm{p}}$ & $* *,-0.60$ & $* * *,-0.74$ & \\
\hline
\end{tabular}

zPhysical properties data were collected from five samples represented as means. Analysis performed using the North Carolina State University porometer method (Fonteno, 1996; Fonteno et al., 1995).

${ }^{y}$ Container capacity is (wet weight - oven dry weight) $\div$ volume of the sample.

${ }^{x}$ Air space is the volume of water drained from the sample $\div$ volume of the sample.

${ }^{\mathrm{w}}$ Total porosity $=$ container capacity + air space.

${ }^{\mathrm{D}} \mathrm{DAP}=$ days after planting.

uRoot dry mass from washed root systems and oven-dried.

${ }^{t}$ Means separated between planted and fallow rhizometers for each DAP of individual physical properties using least significant difference (LSD), $P \leq 0.05$. Means followed by the same letter are not significantly different.

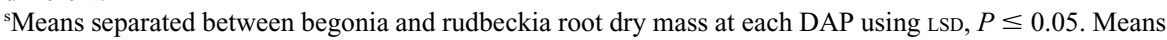
followed by the same letter are not significantly different.

${ }^{\mathrm{r}} \mathrm{NS}, \mathrm{L}$, and Q represent no significant response, linear, and quadratic response, respectively, of individual physical properties over time, $*, * *, * *$ represent significant effects when $P \leq 0.05,0.01$, and 0.001 , respectively.

${ }^{\mathrm{q}_{\mathrm{NS}}}, *, * *, * * *$ represent no significant effect, or significant effects when $P \leq 0.05,0.01$, and 0.001 , respectively.

pNumbers represent correlation coefficients $(\mathrm{n}=20)$ when $P \leq 0.005$.

physical properties and root mass of the two species, only begonia roots were shown to have correlations with the substrate physical properties over time (Table 2). There was a negative correlation $(P \leq 0.005)$ between begonia root mass and $\mathrm{CC}, \mathrm{AS}$, and $\mathrm{TP}$ indicating that as root mass increased over time, these substrate physical properties decreased over time.

Measuring roots in the rhizometer. Results from the rhizometers with zinnia and marigold were similar to the previous studies conducted. Air space and TP were lower at several measurement dates in the zinnia and marigold-planted rhizometers compared with fallow rhizometers (Tables 1 and 3). Container capacity was not different between the fallow and plant rhizometers for either species, except at 21 DAP when fallow had decreased CC. Data from these studies indicate that growing roots have a significant effect on AS and with zinnia, an effect on TP.

Roots were easily traced around the rhizometer as a result of the clear materials used in creating the rhizometer. These traced root images are a non-destructive method for measuring root growth. Both zinnia and marigold species had root tracings significantly correlated to dry root mass with correlation coefficients analyzed to be 0.66 for marigold $(P=0.0016)$ and 0.78 for zinnia $(P=0.0001)$ with a positive correlation between the two variables for both species. This indicates that as root mass increases, total root length (measured from the tracings) increases as well. This indicates that measuring total root length/tracing roots may be an additional and non-destructive method for describing root systems. The correlation for zinnia roots appears to be a linear relationship, whereas the correlation for marigold roots appears to be curvilinear (Fig. 3). Zinnia roots were similar in mass to marigold roots; however, total root length for zinnia was over twice that of marigold roots at 28 DAP. Differences in root types and architecture are possible explanations for this, because zinnia roots compared with marigold roots may be thinner and longer. Rajaniemi and Reynolds (2004) had similar findings with positively correlating traced root lengths with root biomass. They observed that plants that produced a high root biomass were able to grow roots throughout a large volume of 
Table 3. Physical properties of 3 peat: 1 perlite: 1 vermiculite (by volume) substrate with or without the presence of 'Zahara Cherry' zinnia (Zinnia marylandica) growing in the rhizometer and root dry weight data over 4 weeks in 2014.

\begin{tabular}{|c|c|c|c|c|c|}
\hline \multirow[b]{3}{*}{ Rhizometer } & \multirow[b]{3}{*}{ DAP $^{v}$} & \multicolumn{3}{|c|}{ Physical properties ${ }^{z}$} & \multirow[b]{3}{*}{ Root dry mass ${ }^{\mathrm{u}}(\mathrm{g}$} \\
\hline & & $\overline{\text { Container capacity }}{ }^{y}$ & Air space & Total porosityw & \\
\hline & & \multicolumn{3}{|c|}{$(\% \mathrm{vol})$} & \\
\hline \multirow[t]{5}{*}{ Planted } & 7 & $76.0 \mathrm{a}^{\mathrm{t}}$ & $10.6 \mathrm{a}$ & $86.6 \mathrm{~b}$ & $0.10 \mathrm{c}^{\mathrm{s}}$ \\
\hline & 14 & $76.7 \mathrm{a}$ & $9.4 \mathrm{~b}$ & $86.1 \mathrm{~b}$ & $0.21 \mathrm{bc}$ \\
\hline & 21 & $78.3 \mathrm{a}$ & $7.8 \mathrm{~b}$ & $86.1 \mathrm{~b}$ & $0.30 \mathrm{~b}$ \\
\hline & 28 & $78.8 \mathrm{a}$ & $8.6 \mathrm{a}$ & $87.4 \mathrm{a}$ & $0.50 \mathrm{a}$ \\
\hline & & $\mathrm{L} * * \mathrm{r}$ & $\mathrm{L}^{*}$ & $\mathrm{Q}^{*}$ & $\mathrm{~L}^{* * *}$ \\
\hline \multirow[t]{5}{*}{ Fallow } & 7 & $75.7 \mathrm{a}$ & $14.8 \mathrm{a}$ & $90.5 \mathrm{a}$ & \\
\hline & 14 & $77.5 \mathrm{a}$ & $14.2 \mathrm{a}$ & $91.7 \mathrm{a}$ & \\
\hline & 21 & $75.9 \mathrm{~b}$ & $12.7 \mathrm{a}$ & $88.7 \mathrm{a}$ & \\
\hline & 28 & $77.0 \mathrm{a}$ & $12.0 \mathrm{a}$ & $89.1 \mathrm{a}$ & \\
\hline & & NS & NS & NS & \\
\hline Plant & & $\mathrm{NS}^{\mathrm{q}}$ & $* * *$ & $* * *$ & \\
\hline Root dry mass & & NS & NS & NS & \\
\hline Interaction & & NS & NS & NS & \\
\hline
\end{tabular}

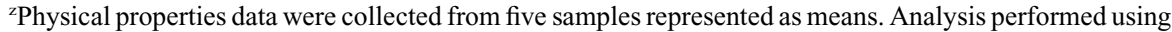
the North Carolina State University porometer method (Fonteno, 1996; Fonteno et al., 1995).

${ }^{y}$ Container capacity is (wet weight - oven dry weight) $\div$ volume of the sample.

xAir space is the volume of water drained from the sample $\div$ volume of the sample.

wTotal porosity $=$ container capacity + air space.

${ }^{v} \mathrm{DAP}=$ days after planting.

"Root dry mass from washed root systems and oven-dried.

'Means separated between planted and fallow rhizometers for each DAP of individual physical properties using least significant difference (LSD), $P \leq 0.05$. Means followed by the same letter are not significantly different.

${ }^{\mathrm{s}}$ Means separated within column for root dry mass using LSD, $P \leq 0.05$. Means followed by the same letter are not significantly different.

${ }^{\mathrm{r}} \mathrm{NS}, \mathrm{L}$, and Q represent no significant response, linear, and quadratic response, respectively, of individual physical properties over time, ${ }^{*}, * *, * * *$ represent significant effects when $P \leq 0.05,0.01$, and 0.001 , respectively. ${ }_{\mathrm{q}} \mathrm{NS}, *, * * * * *$ represent no significant effect, or significant effects when $P \leq 0.05,0.01$, and 0.001 , respectively.
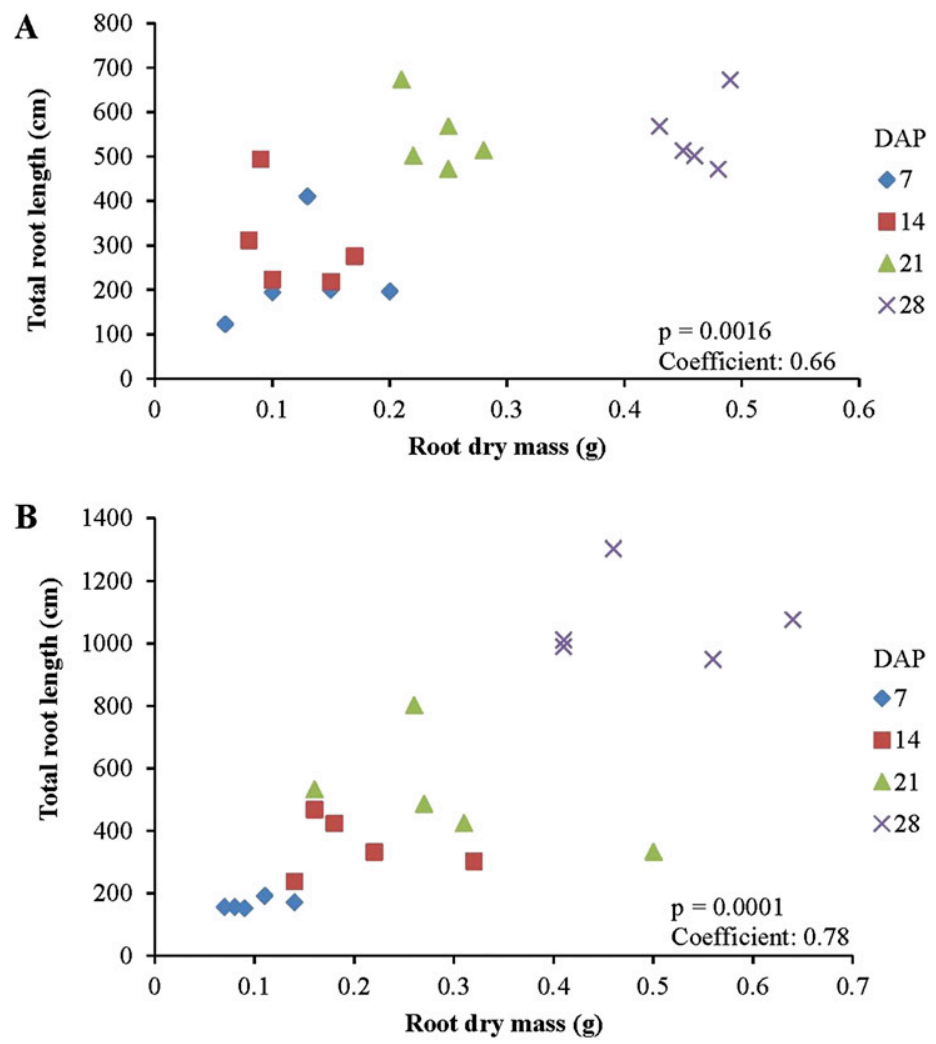

Fig. 3. Correlation between dry root mass and total root length measured in the rhizometers of (A) marigold (Tagetes erecta 'Inca Orange') and (B) zinnia (Zinnia marylandica 'Zahara Cherry') plants at every measurement date with correlation coefficients of $0.66(P=0.0016)$ and $0.78(P=0.0001)$, respectively. The correlation coefficients are a number that summarizes the direction and closeness of linear relationships between the two variables. soil and also produced extensive structural roots (Rajaniemi and Reynolds, 2004).

\section{Conclusion}

With such a large portion of the industry involved with growing plants in containers, it is important to understand how root growth influences substrates used in container production. These studies indicate that the rhizometer has the capability to measure physical properties of substrates either with or without the presence of a plant over time. The studies provide evidence that growing root systems affect the substrate physical properties, most likely a result of a reduction in the macropores in the substrate and simultaneously decreasing the TP over time. The rhizometer can also measure the effects of different plant root types on substrate physical properties, and data from the rhizometers provided evidence that different plant root systems affect the substrate differently. Results indicate that plants with smaller root systems may affect substrate physical properties less than plants with larger, more vigorous root systems. The rhizometers can easily be filled with different substrates, enabling a wide variety of materials to be tested. The clear cylinder of the rhizometer aids in functionality and allows for many different root observations and measurements to be made to further understand and quantify root growth of plants during production. The two plant species used in these studies indicate a strong correlation between the traced and measured total root length (of visible roots along the rhizometer core) and dry root mass of the entire root system once separated from substrate. Using a measuring technique such as digital imaging would allow for repeated, non-destructive root measurement. Measuring visible root lengths can also be used to compare roots systems (different treatments, species, etc.). However, it has limitations because it only measures the visible roots on the outside of the substrate and cannot completely assess root growth of plants in containers (root architecture, root diameter) as a result of many of the roots still not visible inside the substrate.

\section{Literature Cited}

Aendekerk, T.G. 1997. Decomposition of peat substrates in relation to physical properties and growth of Chamaecyparis. Acta Hort. 450:191-198.

Allaire-Leung, S.E., J. Caron, and L.E. Parent. 1999. Changes in physical properties of peat substrates during plant growth. Can. J. Soil Sci. 79:137-139.

Altland, J.E., J.S. Owen, Jr., and M.Z. Gabriel. 2011. Influence of pumice and plant roots on substrate physical properties over time. HortTechnology 21:554-557.

Baligar, V.C. and V.E. Nash. 1978. Sorghum root growth as influenced by soil physical properties. Commun. Soil Sci. Plant Anal. 9:583-594.

Bilderback, T.E. and W.C. Fonteno. 1987. Effects of container geometry and media physical properties on air and water volumes in containers. J. Environ. Hort. 5:180-182. 
Bilderback, T.E., S.L. Warren, J.S. Owen, and J.P. Albano. 2005. Healthy substrates need physicals too! HortTechnology 15:747-751.

Bunt, A.C. 1988. Media and mixes for container grown plants: A manual on the preparation and use of growing media for pot plants. 2nd Ed. Unwin Hyman, London, UK.

Cannavo, P., H. Hafdhi, and J.-C. Michel. 2011. Impact of root growth on the physical properties of peat substrate under a constant water regimen. HortScience 46:1394-1399.

Cannavo, P. and J.-C. Michel. 2013. Peat particle size effects on spatial root distribution, and changes on hydraulic and aeration properties. Sci. Hort. 151:11-21.

Clark, R.T., A.N. Famoso, K. Zhao, J.E. Shaff, E.J. Craft, C.D. Bustamante, S.R. McCouch, D.J. Aneshansley, and L.V. Kochian. 2013. Highthroughput two-dimensional root system phenotyping platform facilitates genetic analysis of root growth and development. Plant Cell Environ. 36:454-466.

Fonteno, W.C. 1996. Growing media: Types and physical/chemical properties, p. 93-122. In: Reed, D.W. (ed.). Water, media, and nutrition for greenhouse crops. Ball Publishing, Batavia, IL.

Fonteno, W.C., C.T. Hardin, and J.P. Brewster. 1995. Procedures for determining physical properties of horticultural substrates using the NCSU Porometer. Horticultural Substrates
Laboratory, North Carolina State University, Raleigh, NC.

Goss, M.J. 1977. Effects of mechanical impedance on root growth in barley (Hordeum vulgare L.). J. Expt. Bot. 28:96-111.

Jackson, B.E., R.D. Wright, and M.C. Barnes. 2008. Pine tree substrate, nitrogen rate, particle size, and peat amendment affect poinsettia growth and substrate physical properties. HortScience 43:2155-2161.

Lobet, G., X. Draye, and C. Perilleux. 2013. An online database for plant image analysis software tools. Plant Methods 9:1-7.

Mathers, H.M., S.B. Lowe, C. Scagel, D.K. Struve, and L.T. Case. 2007. Abiotic factors influencing root growth of woody nursery plants in containers. HortTechnology 17:151-162.

Nelson, P.V., Y.M. Oh, and D.K. Cassel. 2004. Changes in physical properties of coir dust substrates during crop production. Acta Hort. 644:261-268.

Oliveira, M.R.G., M. van Noordwijk, S.R. Gaze, G. Brouwer, S. Bona, G. Mosca, and K. Hairiah. 2000. Auger sampling, ingrowth cores and pinboard methods, p. 175-210. In: Root methods: A handbook. Springer-Verlag, Berlin, Germany.

Owen, J.S., S.L. Warren, T.E. Bilderback, D.K. Cassel, and J.P. Albano. 2008. Physical properties of pine bark substrate amended with industrial mineral aggregate. Acta Hort. 779:131-138.

Polak, A. and R. Wallach. 2001. Measuring soil moisture dynamics in an irrigated orchard by time domain reflectrometry method. Acta Hort. 562:39-46.

Rajaniemi, T.K. and H.L. Reynolds. 2004. Root foraging for patchy resources in eight herbaceous plant species. Oecologia 141:519-525.

Silva, D.D. and R.C. Beeson, Jr. 2011. A largevolume rhizotron for evaluating root growth under natural-like soil moisture conditions. HortScience 46:1677-1682.

U.S. Department of Agriculture. 2009. Census of agriculture, 2007 summary and state data. 3 Dec. 2012. <http://www.agcensus.usda.gov/ Publications/2007/Full_Report/usv1.pdf $>$.

van Noordwijk, M. and J. Floris. 1979. Loss of dry weight during washing and storage of root samples. Plant Soil 53:239-243.

Warren, S.L. and T.E. Bilderback. 1992. Arcillite: Effect on chemical and physical properties of pine bark substrate and plant growth. J. Environ. Hort. 10:63-69.

Wiersum, L.K. 1957. The relationship of the size and structural rigidity of pores to their penetration by roots. Plant Soil 9:75-85.

Wright, A.N. and R.D. Wright. 2004. The Horhizotron $^{\mathrm{TM}}$ : A new instrument for measuring root growth. HortTechnology 14:560-563. 